\title{
Comparison on Genders, Ethnics, and Academic Ranks among Faculty Members on Academic Leadership and Work-Related Attitudes
}

\section{Muhammad Hasmi Abu Hassan Asaari, Nasina Mat Desa}

To Link this Article: http://dx.doi.org/10.6007/IJARBSS/v11-i3/8981

DOI:10.6007/IJARBSS/v11-i3/8981

Received: 06 January 2021, Revised: 01 February 2021, Accepted: 26 February 2021

Published Online: 19 March 2021

In-Text Citation: (Asaari \& Desa, 2021)

To Cite this Article: Asaari, M. H. A. H., \& Desa, N. M. (2021). Comparison on Genders, Ethnics, and Academic Ranks among Faculty Members on Academic Leadership and Work-Related Attitudes. International Journal of Academic Research in Business and Social Sciences, 11(3), 733-748.

Copyright: (c) 2021 The Author(s)

Published by Human Resource Management Academic Research Society (www.hrmars.com)

This article is published under the Creative Commons Attribution (CC BY 4.0) license. Anyone may reproduce, distribute, translate and create derivative works of this article (for both commercial and non-commercial purposes), subject to full attribution to the original publication and authors. The full terms of this license may be seen at: http://creativecommons.org/licences/by/4.0/legalcode

Vol. 11, No. 3, 2021, Pg. 733 - 748

Full Terms \& Conditions of access and use can be found at http://hrmars.com/index.php/pages/detail/publication-ethics 


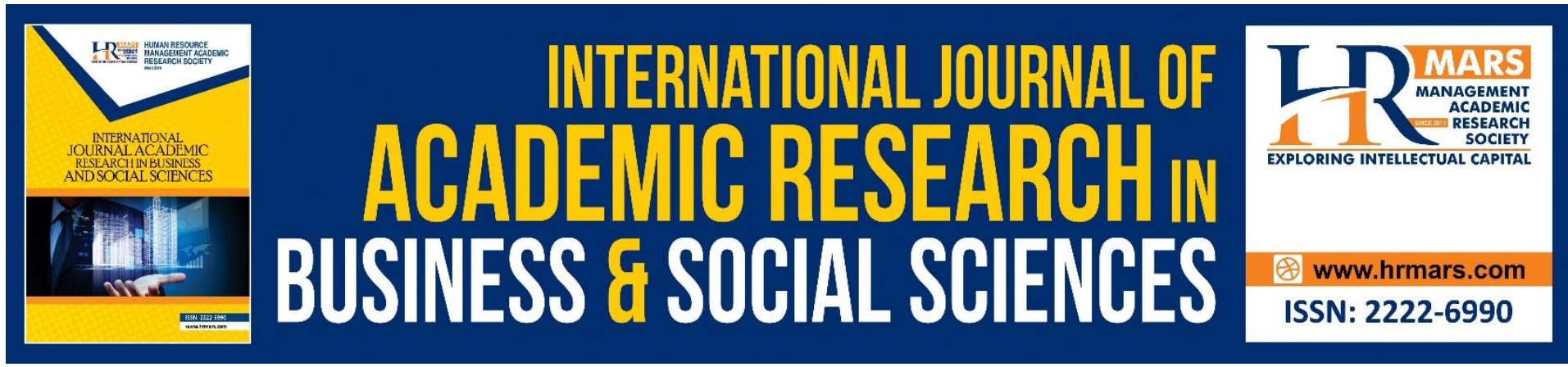

\title{
Comparison on Genders, Ethnics, and Academic Ranks among Faculty Members on Academic Leadership and Work-Related Attitudes
}

\author{
Muhammad Hasmi Abu Hassan Asaari \\ Management Section, School of Distance Education Universiti Sains Malaysia \\ Email: hasmi@usm.my \\ Nasina Mat Desa \\ Management Section, School of Distance Education Universiti Sains Malaysia \\ Email: nasina@usm.my
}

\begin{abstract}
Leadership in the higher education sector has had increased interest by academics and practitioners. This has been partly attributed to the changes that are happening in the higher education environment such as changing funding mechanisms, regulations and audit, increasing customer demands, competition and internationalization, and ongoing reduction in federal resources. However, recent studies have noted that there has been very limited paper conducted on the question of which forms of academic leadership are associated with individual academic performance. Therefore, this paper aims to identify which specific aspects of academic leadership skill-set has the maximum impact on academics' work-related attitudes among gender, ethnics and academic ranks of faculty members in Malaysian public universities. A survey was conducted on faculty members in twenty public universities. Multiple regression analyses were conducted in assessing the relationships and impacts bewteen academic leadership and work-related attitudes.
\end{abstract}

Keywords: Academic Leadership, Work-Related Attitudes, Public Universities, Faculty Members

\section{Introduction}

Academic leadership has not received much coverage in the reviews, especially the issue of identifying leadership approaches in higher education (Favero, 2005). Further, Askling and Stensaker (2002) state that there is much to be gained by papering the practice of leadership in higher education. Koen and Bitzer (2010) highlight the components of academic leadership that they discovered through several interviews with academic leaders. In sum, there is a need for further paper on academic leadership in public organizations especially public universities.

The term academic leadership was coined in the 70s in the work of Blackburn and Gerber (1974). In their paper, they caution the university in employing outsiders as independent experts in measuring the academic leadership and/or institutional quality. They associate 
academic leadership with the measure of academic freedom with regards to research, publications, teaching, citizen rights and continuous employment. Meanwhile the studies on leadership in higher education have been explored since 1988 by Deluga. Deluga (1988) investigates the political nature of leadership by examining the association of the task-people leadership approach with strategies used by subordinates to influence their superiors.

Spendlove's (2007) paper equates the terms of academic leadership and leadership in higher education. Most studies on leadership in higher education talk about the behaviour or leadership style of the leader according to the perceptions of others and their subordinates. In the context of leadership in higher education, the person holds an administrative position in the university. Further some scholars look at leadership in higher education concentrates on how others look at or examine the leader. Moreover, some studies are based on subordinates' perceptions toward the leader in a university. Some studies on academic leadership are based on faculty members' perceptions and explanations about themselves to others. In the context of academic leadership, faculty members need not hold any administrative positions at the university. Faculty members are considered as academic leaders, not because they hold a position (Marshall et al., 2000). Further, faculty members historically served as the source of academic leadership (Strathe \& Wilson, 2006).

Academic leadership definition is derived from the compilation and summarization between scholars' definitions of academic leadership and leadership in higher education. Thus, the paper's definition of academic leadership is a person - faculty member - who has a formal position, professional autonomy and discipline scholarship; who has strategic directions and is competent in teaching, research, community of practice, innovation, teamwork and focuses on students; who can influence, inspire, motivate and transform - all these not just to himor her-self but to other people, colleagues and students.

In an up-to-date review of literature on academic leadership in Malaysia, there are not many studies on academic leadership that relate to the country's higher education. Further, almost no studies are done on public universities. It is crucial for the government of Malaysia to know the level of academic leadership of faculty members. This information could lead the government in planning their human resource needs for the nation's public universities to ensure their faculty members have academic leadership. Moreover, higher management of public universities could gauge themselves alongside the relevant departments and units to provide training and courses for faculty members on their academic leadership. Subsequently, it is expected that the impact of academic leadership among faculty members could provide them with a positive and encouraging performance in terms of faculty members' work-related attitudes.

This paper aims to identify which specific aspects of academic leadership on the following:

1. To examine the relationship between academic leadership and work-related attitudes.

2. To understand the impact of academic leadership on work-related attitudes.

3. To make comparison on gender, ethnics and academic ranks of faculty members in relation to academic leadership and work-related attitudes. 


\section{Literature Review \\ Academic Leadership}

Several studies also equate, or seem to equate, the term academic leadership with leaders in higher education institutions. Ervay (2006) studies academic leadership in America's public schools and defines those who regularly lead decision-making and action-taking processes in curriculum, instruction, and assessment of student learning as academic leaders. Askling and Stansaker (2002) state academic leadership by seeing leadership as a process of social interaction guiding individuals and groups towards particular goals. Meanwhile, Henkel (2002) indicates emerging concepts of academic leadership and their implications for intrainstitutional roles and relationships in higher education requires that deans and heads of department must be both academics and managers and out of the tensions or conflicts inherent in that belief: between individual and collective concerns, hierarchy and community, control and support, change and continuity.

Based on reviews, academic leadership is defined according to the studies context. McNamara (2009) studies academic leadership in nursing and states that academic leadership is directed towards building meaningful partnerships between clinical and academic settings and providing the conditions of possibility for the development of clinician-educators who operate at the research-practice interface. Meanwhile, Zhao and Ritchie (2007), in their investigation of academic leadership in tourism research, state that academic leadership refers to the superior capability of some tourism scholars to communicate their research works in accredited tourism journals. Strathe and Wilson (2006) claim that faculty members have historically served as the source of academic leadership through their degree programs for teaching, research and scholarship, and service responsibilities. Further, Murphy (2003) states academic leadership is a complex and demanding role with significant stress and high burnout and turnover rates. Askling and Stensaker (2002) refer to academic leadership as a role carried out formally, almost as an obligation. Further, they look at academic leadership by seeing leadership as a process of social interaction guiding individuals and groups towards particular goals. Marshall, Adams, Cameron and Sullivan (2000) term academic leadership as responsibility within universities (i.e. vice chancellor, dean, and/or head of discipline/department). Meanwhile, Jones and Holdaway (1996) define academic leadership based on activities undertaken by departmental heads, namely programme activities, facultyrelated activities and personal academic activities.

In the reviews of academic leadership several issues are raised such as identifying administrative behaviours (Favero, 2005), analyzing the traditional duties of academic administrators (Hancock, 2007), student evaluation of the university top management (Saktivel, 2007), scrutiny of academic leadership (Bisbee, 2007), studies on Mexican academic leadership-based group experience (Yanez, 2004), training programmes for academic management and leadership for academic leaders (Kekale, 2003), effective leadership decisions and practices (Rowley \& Sherman, 2003), academic leadership development (Jones \& Holdaway, 1996; Brown, 2001), rebuilding academic leadership through identifying the type of faculty members (Piercy, 1999), and the impact of academic leadership on entrepreneurial activities (Rekila, Larimo \& Tauriainen, 1999). Results from Hannagan, Lawton and Mallory (2007) reveal that the components affecting academic leadership include changes in funding mechanisms, autonomy, competition among other academic institutions, teaching staff, centralized decision-making and teamwork. 


\section{Work-Related Attitudes}

Work-related attitudes is reviewed based on the total quality management perspective. Reviews indicate that leadership has an effect on work-related attitudes among workers in organizations (Kidwell \& Valentine, 2008; Bhal, Gulati \& Ansari, 2009; Butler, 2009; Eddleston, 2009; Burke, Koyuncu \& Fiksenbaum, 2008; Dellve, Skagert \& Vilhelmsson, 2007; Jensen \& Luthan, 2006; Tu et al., 2006; Walumbwa et al., 2005a; Walumbwa, Orwa, Wang \& Lawler, 2005b; Karl, Peluchette \& Hartland, 2005; Shirey, 2004; Sagie et al., 2002; Loughlin \& Barling, 2001; Jiang \& Klein, 1999/2000; Hammer, 1978). Luthans (1995) states leaders with positive affect are more likely to have a positive attitude. Meanwhile, Alas and Edwards (2006) claim work-related values as the outcome of the intricate interaction of a number of factors which include the national cultural and institutional context, the specific industry context, the organizational environment and, finally, the characteristics of individual themselves.

The work-related attitudes of faculty administrators is considered similar to that experienced by managers in public and private organizations. Managers in organizations also experience job satisfaction, better relations among their supervisors and subordinates, less stress and good work-related health, happiness at work, build work spirit and trust. Guimareas (1996) conceptualizes several indicators for work-related attitudes such as job satisfaction, career satisfaction and organizational commitment. These indicators will be examined in relation to the faculty administrator's academic leadership.

Further, no studies are found that directly link how academic leadership relates to faculties' broader psychological attachment to the organization and their job as gauged by their job satisfaction, career satisfaction and organizational commitment. Further, this provides an opportunity for this paper to explore the link between the attributes of academic leadership toward work-related attitudes. Moreover, this paper can examine the impact of academic leadership attributes on job satisfaction, career satisfaction and organizational commitment.

Job satisfaction refers to a person's positive affective relation to his/her job (Noordin \& Jusoff, 2010). Job satisfaction is associated with participation which includes enhanced self-esteem, feelings of control, responsibility, task identity and task meaningfulness (Oswald, Hossholder \& Harris, 1994). Further, job satisfaction can be achieved through mentally challenging work, equitable rewards, a supportive working environment and helpful colleagues (Forsyth, 1995). Bhuian and Islam (1996) define job satisfaction as the extent to which a worker feels positively or negatively about his or her job. Job satisfaction comes in the form of compensation, job security, career opportunity and career advancement. Alas and Edwards (2006) state job satisfaction as affective; a pleasurable emotional state resulting from the appraisal of one's work.

Greenhaus et al. (1990) refer to career satisfaction as the overall affective reaction of individuals to their career. A satisfied person is more likely to provide high levels of service to their customers and more likely to remain with the organization, thus reducing staff turnover (Butler, 1996; Kerr, 1996). Further, satisfied leaders have no intention to leave because they are satisfied with their careers (Eddleston, 2009). Only a handful of studies are undertaken on leadership and its impact on career satisfaction. Tu, Forret and Sullivan (2006) indicate that, among Chinese managers, leadership in a middle management position is associated with greater career satisfaction. Further, leadership has been examined in terms of career 
satisfaction and psychological well being in managerial and supervisory positions in the hospitality and tourism industry sector (Burke et al., 2008). Moreover, organizations must understand the relationships between leaders' internal desires, the environment fostered by the organization, and career satisfaction (Jiang \& Klein, 1999/2000). Kubicek (2004) looks at the relationship between mentoring and career success. He finds that leaders who have been mentors achieve more promotions, more salary increases and more career satisfaction. The results from Fahey, Myrtle, Schlosser and Lee (1998) suggest managers who focus on getting the job done, seek opportunities that provide them with early leadership experience and demonstrate an ability to manage change will have careers that are satisfying.

Organizational commitment is commonly conceptualized as an affective attachment to an organization characterized by shared values, a desire to remain in the organization, an action characterized by shared values, a desire to remain in the organization, and a willingness to exert effort on its behalf (Mowday et al., 1979; Allen \& Meyer, 1990). Further, organizational commitment refers to the degree of attachment and loyalty felt by individual employees to the organization (Guimareas, 1996; Luthans, 1995; Mowday et al., 1979; Alas \& Edwards, 2006). Becker (1960) views organizational commitment as a reflection of recognized, accumulated interest that binds one to a particular organization (Bhuian \& Islam, 1996). Other scholars view organizational commitment as an internal feeling, belief, or set of intentions that enhances an employee's desire to remain with an organization (Buchanan, 1974; Porter, Crampton \& Smith, 1976; Bhuian \& Islam, 1996) and an employee's feeling of obligation to stay with the organization (Bhuian \& Islam, 1996), a strong desire to remain a member of the particular organization, and given opportunities to change jobs (Hunt, Chonko \& Wood, 1985; Bhuian \& Islam, 1996). Walumbwa et al. (2005a) and, Walumbwa, Orwa, Wang and Lawler (2005b) state that transformational leadership has a strong and positive effect on organizational commitment. Moreover, Yiing and Ahmad (2009) discovered that leadership styles have a positive and significant relationship with organizational commitment. Employees who are highly committed to their organizations contribute more effectively to company growth and success. The length of time the employees remain with the organization should correlate with their degrees of attachment and loyalty.

\section{Academic Leadership and Work-Related Attitudes}

In conceptualization of academic leadership, this paper uses review of literature from private and public organizations (Alimo-Metcalfe \& Alban-Metcalfe, 2001; Javidan \& Waldman, 2003), and institutions of higher learning (Rowley \& Sherman, 2003; Koen \& Bitzer, 2010). According to Koen and Bitzer (2010), academic leadership is constructed by vision, adaptable to change, competencies, effective leadership and transformational style. Meanwhile, AlimoMetcalfe and Alban-Metcalfe (2001); and Javidan and Waldman (2003) perceive charisma has an impact on leadership. Rowley and Sherman (2003) conceptualize leadership in higher learning where a leader should think of the impact of a decision on enhancing trust, respect, teamwork, good union relations and smooth relations with administrative departments, when making decisions affecting any of the stakeholders. Randall and Coakley (2007) conceptualize that the university must be able to manage equally competing needs from the current market place, have a focus on transactional leadership, transformational leadership, or a combination of both. Further, Randall and Coakley (2007) suggest adaptive leadership to be conceptualized in the higher learning institutions' leadership. Thus this paper conceptualizes academic leadership as formed by vision, being adaptable to change, 
competency, effective leadership, transformational style and charisma. The conceptualization is in the context of the faculty members in the public university. Further, the academic leadership constructs are examined from the perspective of faculty members as individuals.

Work-related attitudes is reviewed based on the total quality management perspective. Reviews indicate that leadership has an effect on work-related attitudes among workers in organizations (Kidwell \& Valentine, 2008; Bhal, Gulati \& Ansari, 2009). Luthans (1995) states leaders with positive affect are more likely to have a positive attitude. Meanwhile, Alas and Edwards (2006) claim work-related values as the outcome of the intricate interaction of a number of factors which include the national cultural and institutional context, the specific industry context, the organizational environment and, finally, the characteristics of individual themselves. The work-related attitudes of faculty administrators is considered similar to that experienced by managers in public and private organizations. Managers in organizations also experience job satisfaction, better relations among their supervisors and subordinates, less stress and good work-related health, happiness at work, build work spirit and trust. Guimaraes (1996) conceptualizes several indicators for work-related attitudes such as job satisfaction, career satisfaction and organizational commitment. These indicators will be examined in relation to the faculty administrator's academic leadership. Further, no studies are found that directly link how academic leadership relates to faculties' broader psychological attachment to the organization and their job as gauged by their job satisfaction, career satisfaction and organizational commitment. Further, this provides an opportunity for this study to explore the link between the attributes of academic leadership toward workrelated attitudes. Moreover, this study can examine the impact of academic leadership attributes on job satisfaction, career satisfaction and organizational commitment.

\section{Methodology}

Population of this paper are faculty members in public universities of Malaysia. By location, the Peninsular has 18 universities; meanwhile in Sabah and Sarawak, there is one each respectively. This gives a total of 20 public universities throughout Malaysia. The population frame is faculty members. The list of faculty members is obtained from the university's academic staff web sites. Data mining of faculty member email addresses is conducted. In this paper, the unit of analysis is the individual faculty member of the public university. The survey questionnaire was done online by faculty members in all public universities by using a premium online survey services. A thousand faculty members of public universities were emailed an invitation to participate in the online survey.

Based on a comprehensive literature review, several research instruments were considered for adaptation and adoption to suit the paper. The Leadership Behaviour Development Questionnaire - Form XII (LBDQ-XII) was selected for this paper. It was developed by Ohio State University, USA (Stogdill, 1963). The questionnaire is freely available from the Fisher College of Business, Ohio State University's website. Further, the use of the LBDQ-XII needs no permission. The LBDQ-XII had been tested on several highly selected samples such as commissioned and non-commissioned officers in an army combat division, the administrative offices in a state highway patrol headquarters office, the executives in an aircraft engineering staff, ministers of various denominations of an Ohio Community, leaders in community development activities throughout the state of Ohio, presidents of 'successful' corporations, presidents of labour unions, presidents of colleges and universities, and United States 
Senators. The LBDQ-XII Cronbach's alpha of the samples was 0.54 to 0.86 across the nine time periods. The LBDQ-XII was also used in various leadership studies such as leadership of German and English managers (Schneider \& Littrell, 2003), leadership behaviour of Chinese managers (Littrell, 2002) and leadership style preference (Lucas, Messner, Ryan \& Sturn, 1992). Schriesheim and Glinow (1977) assert the LBDQ-XII constitutes the most operational accuracy of the theory's leadership construct. Further, Szilagyi and Keller (1976) claimed that the LBDQ-XII initiating structure dimension is significantly and positively related to satisfaction with supervision and overall satisfaction.

Meanwhile, the work-related attitudes instrument was examined from various scholars' works. The job satisfaction measurement was adopted from Weiss et al. (1967). Further, the level of Cronbach's alpha of the job satisfaction measurement was 0.87 . The instrument reliability is the highest compared to the other studies. Thus, the study adopted and adapted a nine-item on job satisfaction (Weiss et al., 1967; Karia \& Asaari, 2006) to inquire about circumstances directed towards selecting a well-constructed scale (Yiing \& Ahmad, 2009). For the past 20 years, career satisfaction had been measured using an instrument from Greenhaus et al. (1990). The initial instrument had a Cronbach's alpha of 0.88. In recent work, the instrument had a Cronbach's alpha of 0.90 (Karia \& Asaari, 2006). Further, ArmstrongStassen and Cameron (2005) reveal a Cronbach's alpha of 0.87 by using Greenhaus et al.'s (1990) instrument. The Organizational Commitment Questionnaire (OCQ) originated from the work of Mowday et al. (1979). The OCQ was used widely in research and was shown to have acceptable psychometric properties (Mowday et al., 1979). The original OCQ instrument consists of 15-items and Cronbach's alpha was 0.82 to 0.93 . Based on the instrument adaptation and adoption, the highest Cronbach's alpha was 0.95 (Karia \& Asaari, 2006).

\section{Results}

A total of 245 responds received which comprised of male $(n=111)$ and female $(n=134)$. In Malaysia there are three major ethnic groups, namely Malays $(n=214)$, Chinese $(n=11)$ and Indian $(n=9)$. Meanwhile according to academic rank, respondents indicated that they were lecturers $(n=92)$, senior lecturers $(n=85)$, assistant professors $(n=8)$, associate professors $(n=30)$ and professors $(n=24)$.

\section{Correlations Analysis}

Table 1 depicts the correlation analysis between independent variables of academic leadership, namely innovative, effective, executive, and adaptive; and dependent variables of work-related attitudes, namely organizational commitment, career satisfaction, job satisfaction, and job skills. The study discovered a strong relationship between academic leadership and work-related attitudes. Meanwhile, innovative was discoved having a strong relationships with job skills ( $r=0.530)$, moderate relationship with organiational commitment $(r=0.417)$ and career satisfaction $(r=0.309)$, and low relationship with job satisfaction $(r=0.171)$. Effective was discovered having a moderate relationship with organizational commitment ( $r=0.347)$ and job skills ( $r=0.385)$; and a low relationship with career satisfaction $(r=0.247)$ and job satisfaction $(r=0.204)$. Executive was discovered having a strong relationship with job skills $(r=0.549)$, a moderate relationship with organizational commitment $(r=0.420)$ and career satisfaction $(r=0.406)$; and a low relationship with job satisfaction $(r=0.296)$. Finally, adaptive was discovered having a moderate relationship with job skills ( $r=0.323)$; and 
a low relationship with organizational commitment $(r=0.277)$, career satisfaction $(r=0.240)$, and job satisfaction $(r=0.230)$.

\begin{tabular}{|c|c|c|c|c|c|c|c|c|c|c|}
\hline & & & & & & & & & & \\
\hline & Item & 2 & 3 & 4 & 5 & 6 & 1 & 8 & 9 & 10 \\
\hline 1 & Innovative & $\begin{array}{c}0.460 \\
*\end{array}$ & $\begin{array}{c}0.650 \\
*\end{array}$ & $\begin{array}{c}0.421 \\
*\end{array}$ & $\begin{array}{c}0.417 \\
*\end{array}$ & $\begin{array}{c}0.309 \\
*\end{array}$ & $\begin{array}{c}0.171 \\
*\end{array}$ & $\begin{array}{c}0.530 \\
*\end{array}$ & $\begin{array}{c}0.814 \\
*\end{array}$ & $\begin{array}{c}0.435 \\
*\end{array}$ \\
\hline 2 & Effective & 1 & $\begin{array}{c}0.564 \\
*\end{array}$ & $\begin{array}{c}0.458 \\
*\end{array}$ & $\begin{array}{c}0.347 \\
*\end{array}$ & $\begin{array}{c}0.247 \\
*\end{array}$ & $\begin{array}{c}0.204 \\
*\end{array}$ & $\begin{array}{c}0.385 \\
*\end{array}$ & $\begin{array}{c}0.778 \\
*\end{array}$ & $\begin{array}{c}0.363 \\
*\end{array}$ \\
\hline 3 & Executive & & 1 & $\begin{array}{c}0.418 \\
*\end{array}$ & $\begin{array}{c}0.420 \\
*\end{array}$ & $\begin{array}{c}0.406 \\
*\end{array}$ & $\begin{array}{c}0.296 \\
*\end{array}$ & $\begin{array}{c}0.549 \\
*\end{array}$ & $\begin{array}{c}0.812 \\
*\end{array}$ & $\begin{array}{c}0.515 \\
*\end{array}$ \\
\hline 4 & Adaptive & & & 1 & $\begin{array}{c}0.277 \\
*\end{array}$ & $\begin{array}{c}0.240 \\
*\end{array}$ & $\begin{array}{c}0.230 \\
*\end{array}$ & $\begin{array}{c}0.323 \\
*\end{array}$ & $\begin{array}{c}0.754 \\
*\end{array}$ & $\begin{array}{c}0.309 \\
*\end{array}$ \\
\hline 5 & $\begin{array}{l}\text { Organizatio } \\
\text { nal } \\
\text { Commitme } \\
\text { nt }\end{array}$ & & & & 1 & $\begin{array}{c}0.512 \\
*\end{array}$ & $\begin{array}{c}0.529 \\
*\end{array}$ & $\begin{array}{c}0.451 \\
*\end{array}$ & $\begin{array}{c}0.463 \\
*\end{array}$ & $\begin{array}{c}0.788 \\
*\end{array}$ \\
\hline 6 & $\begin{array}{l}\text { Career } \\
\text { Satisfaction }\end{array}$ & & & & & 1 & $\begin{array}{c}0.552 \\
*\end{array}$ & $\begin{array}{c}0.547 \\
*\end{array}$ & $\begin{array}{c}0.376 \\
*\end{array}$ & $\begin{array}{c}0.841 \\
*\end{array}$ \\
\hline 7 & $\begin{array}{l}\text { Job } \\
\text { Satisfaction }\end{array}$ & & & & & & 1 & $\begin{array}{c}0.487 \\
*\end{array}$ & $\begin{array}{c}0.290 \\
*\end{array}$ & $\begin{array}{c}0.811 \\
*\end{array}$ \\
\hline 8 & Job Skills & & & & & & & 1 & $\begin{array}{c}0.563 \\
*\end{array}$ & $\begin{array}{c}0.732 \\
*\end{array}$ \\
\hline 9 & $\begin{array}{l}\text { Academic } \\
\text { Leadership }\end{array}$ & & & & & & & & 1 & $\begin{array}{c}0.512 \\
*\end{array}$ \\
\hline 10 & $\begin{array}{l}\text { Work- } \\
\text { Related } \\
\text { Attitudes }\end{array}$ & & & & & & & & & 1 \\
\hline
\end{tabular}

** Correlation is significant at the 0.01 level (2-tailed)

\section{Regression Analysis}

In Table 2, the simple regression analysis was conducted on academic leadership toward work-related attitudes. The trade agency employees had the adjusted $\mathrm{R}^{2}$ value showed $26 \%$ for the dependent variable of work-related attitude, which was explained by the academic leadership. This means that $74 \%$ of the variance for work-related attitudes was explained by other unknown additional variables that have not been explored. The simple regression model $(F=37.36, p<0.00)$ was proven to be a significant model due to the $F$ ratio being significant in predicting work-related attitudes. Academic leadership $(\beta=0.819, p<0.00)$ was a significant predictor of work-related attitude. This explained that the academic leadership was positively related to work-related attitudes among respondents. Therefore, hypothesis $\mathrm{H}_{1}$ is supported in explaining the employees on their academic leadership and work-related attitudes. 
Table 2: Simple Regression Analysis

\begin{tabular}{|c|c|c|}
\hline & \multicolumn{2}{|c|}{ Work-Related Attitude } \\
\hline & $\beta$ & Sig. \\
\hline $\begin{array}{l}\text { Academic } \\
\text { Leadership }\end{array}$ & 0.819 & 0.000 \\
\hline $\mathrm{R}^{2}$ & \multicolumn{2}{|c|}{0.262} \\
\hline Adj. $R^{2}$ & \multicolumn{2}{|c|}{0.259} \\
\hline F-Change & \multicolumn{2}{|c|}{74.931} \\
\hline Sig. & \multicolumn{2}{|c|}{0.000} \\
\hline
\end{tabular}

\section{Discussions}

\section{Gender}

Table 3 shows the comparison between male and female faculty members of public universities in Malaysia. Male faculty members' executive has a relationship with organizational commitment, career satisfaction, job satisfaction and job skills. Male faculty members' innovative has an impact with job skills. Unfortunately, their effective and adaptive has no relationship with any of the work-related attitudes factors. Meanwhile their female counterpart indicates executive has a relationship with career satisfaction and job skills. Females' innovative has an impact with organizational commitment and job skills. Their adaptive has a relationship with job satisfaction. Unfortunately for female faculty members, their effective has no relationship with any of the work-related attitudes factors.

Table 3: Comparison between Gender: Male and Female

\begin{tabular}{|l|r|r|r|r|r|r|r|r|}
\hline & \multicolumn{4}{|c|}{ Male } & \multicolumn{4}{c|}{ Female } \\
\cline { 2 - 9 } & OC & CS & JS & JSK & OC & CS & JS & JSK \\
\hline $\begin{array}{l}\text { Innovativ } \\
\text { e }\end{array}$ & 0.118 & 0.526 & 0.836 & $\begin{array}{r}* * 0.00 \\
2\end{array}$ & $\begin{array}{r}* * * 0.00 \\
0\end{array}$ & 0.435 & 0.428 & $* 0.087$ \\
\hline Effective & 0.831 & 0.760 & 0.506 & 0.665 & 0.527 & 0.530 & 0.816 & 0.915 \\
\hline Executive & $* * 0.00$ & $* * * 0.00$ & $* * 0.00$ & $* 0.036$ & 0.874 & $* * 0.03$ & 0.112 & $* * * 0.00$ \\
& 5 & 0 & 8 & & & 7 & & 1 \\
\hline Adaptive & 0.768 & 0.875 & 0.192 & 0.139 & 0.296 & 0.450 & $* 0.09$ & 0.997 \\
& & & & & & & 7 & \\
\hline
\end{tabular}

${ }^{*} \mathrm{p}<0.1 ; * * \mathrm{p}<0.5 ; * * * \mathrm{p}<0.001$

Note: OC - Organizational commitment; CS - Career satisfaction; JS - Job skills; JSK - Job skills

Comparison between genders, the executive of academic leadership has been regarded as important by male faculty members in academia. They perceive of having the power and authority satisfy their work-related attitudes, namely organizational commitment, career satisfaction, job satisfaction and job skills. Further male faculty members use power and authority in their way of handling classes and students, research activities and administrative duties. Apart they also perceive the innovative of academic leadership has an influence on their job skills. The executive and innovative of academic leadership of male faculty members are seen as a harmony combination as they blend both factors onto their teaching and learning, research activities, writings and publications, and administrative duties in terms of academic and non-academic. Meanwhile for female faculty members, they state that 
executive of academic leadership influence their career satisfaction and job skills. Female faculty members perceive innovative of academic leadership influence their organizational commitment and job skills. This can be said that female faculty members could satisfy their job skills by having executive and innovative in their academic leadership. In this context, female faculty members are seen of not enjoying as much authority and power as compared to their male counterpart. Thus the top management of public universities can promote various courses and trainings to their male and female faculty members toward enhancing their academic leadership. Innovative trainings that relate to research grants and writing for publications could improve faculty members' work-related attitudes. Meanwhile the exposure of executive in terms of power and authority could help faculty members to be effective in handling academic and non-academic administrative duties.

\section{Ethnics}

Malays are the majority faculty members in the Malaysian public universities as compared to non-Malays, namely Chinese and Indians. Based on comparison among ethnics, Malays show that executive, innovative and adaptive of academic leadership have a relationship with organizational commitment, career satisfaction, job satisfaction and job skill. Meanwhile, non-Malays indicate innovative of academic leadership has a relationship with career satisfaction in academia. Table 4 shows the comparison between Malays and non-Malays of their academic leadership and work-related attitudes.

Table 4: Comparison between Ethnicity: Malays and Non-Malays

\begin{tabular}{|l|r|r|r|r|r|r|r|c|}
\hline \multirow{2}{*}{} & \multicolumn{4}{|c|}{ Malays } & \multicolumn{4}{c|}{ Non-Malays } \\
\cline { 2 - 10 } & \multicolumn{1}{|c|}{ OC } & \multicolumn{1}{c|}{ CS } & \multicolumn{1}{c|}{ JS } & \multicolumn{1}{c|}{ JSK } & \multicolumn{1}{c|}{ OC } & \multicolumn{1}{c|}{ CS } & JS & JSK \\
\hline Innovative & $* * * 0.000$ & 0.596 & 0.407 & $* * * 0.001$ & 0.406 & $* * 0.027$ & 0.927 & 0.142 \\
\hline Effective & 0.799 & 0.462 & 0.863 & 0.933 & 0.186 & 0.573 & 0.791 & 0.655 \\
\hline Executive & $* 0.053$ & $* * * 0.000$ & $* * 0.004$ & $* * * 0.000$ & 0.676 & 0.568 & 0.384 & 0.447 \\
\hline Adaptive & 0.242 & 0.500 & $* 0.015$ & 0.227 & 0.805 & 0.740 & 0.876 & 0.496 \\
\hline
\end{tabular}

$* \mathrm{p}<0.1 ; *{ }^{*} \mathrm{p}<0.5 ; * * * \mathrm{p}<0.001$

Note: OC - Organizational commitment; CS - Career satisfaction; JS - Job skills; JSK - Job skills

Interestingly, Malays faculty members show that executive of academic leadership has a significant impact on their work-related attitudes, namely organizational commitment, career satisfaction, job satisfaction and job skills. Therefore as the public universities in Malaysia give the opportunity to faculty members the transformational freedom in academia, this has confirmed that executive has a high regards among Malays faculty members. Further, Malays faculty members claim innovative of academic leadership has an impact on their organizational commitment and job skills. Meanwhile for non-Malays faculty member, they regard innovative of academic leadership has an impact on their career satisfaction. As such non-Malays faculty members are satisfied if they can be innovative in academia.

\section{Academic Ranks}

In the Malaysian public universities, academic ranks are identified as lecturers, senior lecturer, assistant professors, associate professors and professors. Lecturers could be young faculty members up to 5 years of experience. Senior lecturers and assistant professors are those with more than 5 years in teaching experience with publications and research works. Associate professors are those who are between 5 to 10 year of teaching experience with 
extensive publications, research works and recognitions at local and international. Professors are for those with years of experience in teaching, publications, research works, community involvements and recognitions. Table 5 shows the analysis of academic rank's academic leadership and work-related attitudes.

Table 5: Comparison between Academic Ranks

\begin{tabular}{|l|r|r|r|r|r|r|r|r|}
\hline \multirow{2}{*}{} & \multicolumn{4}{|c|}{ Lecturers } & \multicolumn{4}{c|}{ Senior Lecturers } \\
\cline { 2 - 10 } & OC & \multicolumn{1}{|c|}{ CS } & \multicolumn{1}{c|}{ JS } & JSK & OC & CS & JS & \multicolumn{1}{c|}{ JSK } \\
\hline Innovative & $* * 0.002$ & 0.398 & 0.545 & $* 0.024$ & 0.902 & 0.500 & 0.304 & $* * 0.031$ \\
\hline Effective & 0.733 & 0.116 & 0.151 & 0.519 & 0.235 & 0.604 & 0.638 & 0.845 \\
\hline Executive & 0.311 & $* * * 0.000$ & $* * 0.004$ & 0.000 & 0.303 & 0.114 & 0.272 & 0.571 \\
\hline Adaptive & 0.575 & 0.669 & 0.343 & 0.636 & $* 0.097$ & 0.112 & $* 0.011$ & $* 0.100$ \\
\hline
\end{tabular}

Note: OC - Organizational commitment; CS - Career satisfaction; JS - Job skills; JSK - Job skills

Table 5: Comparison among Academic Ranks (Continue)

\begin{tabular}{|l|r|r|r|r|r|r|r|r|r|r|r|r|}
\hline & \multicolumn{4}{|c|}{ Assistant Professors } & \multicolumn{4}{|c|}{ Associate Professors } & \multicolumn{4}{|c|}{ Professors } \\
\cline { 2 - 13 } & \multicolumn{1}{|c|}{ OC } & \multicolumn{1}{c|}{ CS } & \multicolumn{1}{c|}{ JS } & \multicolumn{1}{|c|}{ JSK } & \multicolumn{1}{c|}{ OC } & \multicolumn{1}{c|}{ CS } & \multicolumn{1}{c|}{ S } & JSK & OC & CS & JS & JSK \\
\hline Innovat & 0.3 & 0.1 & $* 0.01$ & 0.1 & $* 0.01$ & 0.8 & 0.3 & 0.1 & 0.538 & 0.8 & 0.8 & 0.5 \\
ive & 34 & 07 & 3 & 56 & 4 & 06 & 91 & 51 & & 31 & 56 & 93 \\
\hline Effectiv & 0.3 & 0.3 & 0.020 & 0.1 & 0.483 & 0.5 & 0.9 & 0.9 & $* * 0.0$ & 0.1 & 0.1 & 0.7 \\
e & 74 & 06 & & 60 & & 50 & 47 & 50 & 33 & 88 & 89 & 40 \\
\hline Executi & 0.9 & 0.1 & $* * 0.0$ & 0.9 & $* * 0.0$ & 0.9 & 0.8 & 0.3 & 0.170 & 0.7 & 0.9 & 0.3 \\
ve & 09 & 06 & 42 & 98 & 49 & 24 & 36 & 46 & & 91 & 99 & 49 \\
\hline Adaptiv & 0.5 & 0.3 & 0.330 & 0.8 & 0.205 & 0.7 & 0.4 & 0.2 & 0.159 & 0.9 & 0.1 & 0.5 \\
e & 25 & 03 & & 02 & & 28 & 71 & 38 & & 47 & 65 & 34 \\
\hline
\end{tabular}

$* \mathrm{p}<0.1 ;{ }^{* *} \mathrm{p}<0.5 ;{ }^{* * *} \mathrm{p}<0.001$

Note: OC - Organizational commitment; CS - Career satisfaction; JS - Job skills; JSK - Job skills

\section{Conclusion}

Academic leadership, in this paper, is concerned with faculty members' attributes which lead to their sustainabilitity in the world of academia. Thus, the attributes of academic leadership are explored from inside-to-outside from the individual faculty members. This paper allows faculty members to think, self-portrait, self-report, and self-reflect on their own academic leadership toward their individual performance. The study contributes that academic leadership of faculty members are associated with their work-related attitudes. Moreover, the study's hypothesis confirms that academic leadership has an impact on the faculty members' work-related attitudes.

In the context of faculty members in the Malaysian public unversities, executive of academic leadership plays a significant and important factor in faculty members' work-related attitudes, namely organizational commitment, career satisfaction, job satisfaction and job skills. These could be seen in gender, especially male faculty members; ethnics, especially Malays faculty members; and academic rank, especially lecturers, assistant professors, associate professors and professors. Significantly, the study provides the top management of public unversities need to take certain measure in order to educate and train their faculty 
members in dealing with their power and authority on their classes and students, researh activities, and academic and non-academic administrative functions.

This study opens up an opportunity to explore faculty members in private universities on their academic leadership, namely innovative, effective, executive and adaptive; and work-related attitudes, namely organizational commitment, career satisfaction, job satisfaction and job skills. Moreover, comparison between faculty members in public and private universities also could be explored in other studies.

\section{Acknowledgement}

The authors would like to acknowledge the contributions made by the Universiti Sains Malaysia under the grant funding on this paper publication. No. 1001/PJJAUH/8016077. Earlier paper was presented at the Cambridge Business and Economic Conference, Oxford, United Kingdom. 2-3 July 2013.

\section{References}

Alas, R., \& Edwards, V. (2006). Work-related attitudes in Finno-Ugrian countries: Estonia, Finland and Hungary. AIB-SE (USA) 2006 Annual Meeting. Clearwater Beach, FL, USA.

Alimo-Metcalfe, B., \& Alban-Metcalfe, J. (2001). The development of a new transformational leadership questionnaire. Journal of Occupational and Organizational Psychology, 74, 1-27.

Allen, N. J., \& Meyer, J. P. (1990). The measurement and antecedents of affective, continuance and normative commitment to the organization, Journal of Occupational Psychology, 63, 1-18.

Armstrong-Stassen, M., \& Cameron, S. (2005). Factors related to the career satisfaction of older managerial and professional women. Career Development International, 10(3), 203-215.

Askling, B., \& Stensaker, B. (2002). Academic leadership: prescriptions, practices and paradoxes. Tertiary Education and Management, 8, 13-125.

Becker, H. S. (1960). Notes of the concept of commitment. American Journal of Sociology, 66, 32-42.

Bhal, K. T., Gulati, N., \& Ansari, M. A. (2009). Leader-member exchange and subordinate outcomes: test of a mediation model. Leadership \& Organization Development Journal, 30(2), 106-125.

Bhuian, S. N., \& Islam, M. S. (1996). Continuance commitment and extrinsic job satisfaction among a novel multicultural expantriate workforce. Mid-Atlantic Journal of Business, 32(1), 35-46.

Bisbee, D. C. (2007). Looking for leaders: Current practices in leadership identification in higher education. Planning and Changing, 38(1\&2), 77-88.

Blackburn, R. T., \& Gerber, W. J. (1974). Expert Rating on Academic Leadership as a Measure of Institutional Quality, Sociology of Education, 47(4), 535-540.

Brown, L. M. (2001). Leading leadership development in universities: A personal story. Journal of Management Inquiry, 10(4), 312-323.

Buchanan, B. (1974). Building organizational commitment: the socialization of managers in work organizations. Administrative Science Quarterly, 19, 533-546.

Burke, R. J., Koyuncu, M., \& Fiksenbaum, L. (2008). Work experiences, satisfactions and 
psychological well-being of female and male managers in the hospitality sector in Turkey. Equal Opportunities International, 27(6), 505-510.

Butler, C. (2009). Leadership in a multicultural Arab organization. Leadership \& Organization Development Journal, 30(2), 139-151.

Butler, D. (1996). A comprehensive survey on how companies improve performance through quality efforts. California: David Butler Associates, Inc.

Dellve, L., Skagert, K., \& Vilhelmsson, R. (2007). Leadership in workplace health promotion projects: 1- and 2-year effects on long-term work attendance. European Journal of Public Health, 17(5), 471-476.

Deluga, R. J. (1988). Relationship of transformational and transactional leadership with employee influencing strategies, Group Organization Management, 13(4), 456-467.

Eddleston, K. A. (2009). The effects of social comparison on managerial career satisfaction and turnover intentions. Career Development International, 14(1), 87-110.

Ervay, S. (2006). Academic leadership in America's public schools, NASSP Buletin, June, 90, 277-286.

Fahey, D. F., Myrtle, R. C., Schlosser, J. R., \& Lee, D. M. (1998). Critical success factors in the development of healthcare management careers. Journal of Health Management, 43(4), 307-320.

Favero, M. (2006). Disciplinary variation in preparation for the academic dean role. Higher Education Research and Development, 25(3), 277-292.

Forsyth, A. (1995). Gender, planning and the policy process. Journal of the American Planning Association, 61(2), 276-277.

Greenhaus, J. H., Parasuraman, S., \& Wormley, W. M. (1990). Effects race on organizational experiences, job performance evaluations and career outcome. Academy of Management Journal, 33(1), 64-86.

Guimaraes, T. (1996). TQM's impact on employee attitudes. The TQM Magazine, 8(1), 2025.

Hammer, T. H. (1978). Relationships between local union characteristics and workers behavior and attitudes. Academy of Management Journal, 21(4), 560-577.

Hancock, T. M. (2007). The business of universities and the role of department chair. International Journal of Educational Management, 21(4), 306-314.

Hannagan, T., Lawton, A., \& Mallory, G. (2007). Responding to change: The management of further education college in England. International Journal of Public Sector Management, 20(6). 484-496.

Henkel, M. (2002). Emerging concepts of academic leadership and their implications for intra-institutional roles and relationships in higher education. European Journal of Education, 37, 29-41.

Hunt, S. D., Chonko, L. B., \& Wood, V. R. (1985). Organizational commitment and marketing. Journal of Marketing, 49, 112-126.

Javidan, M., \& Waldman, D. A. (2003). Exploring charismatic leadership in the public sector: measurement and consequences. Public Administration Review, 63(2), 229-242.

Jensen, S. M., \& Luthans, F. (2006). Entrepreneurs as authentic leaders: impact on employees' attitudes. Leadership \& Organization Development Journal, 27(8), 646-666.

Jiang, J. J., \& Klien, G. (1999/2000). Supervisor support and caree anchor impact on the career satisfaction of the entry-level information system professional. Journal of Management Information System, 16(3), 219-230.

Jones, D. R., \& Holdaway, E. A. (1996). Post-secondary department heads: expectations for 
academic leadership and authority. International Journal of Educational Management, 10(3), 10-20.

Karia, N., \& Asaari, M. H. A. H. (2006). The effects of total quality management practices on employees' work-related attitudes. The TQM Magazine, 18(1), 30-43.

Karl, K., Peluchette, J., \& Harland, L. (2005). Attitudes toward workplace fun: a three sector comparison. Journal of Leadership \& Organizational Studies, 12(2), 1-17.

Kekale, J. (2003). Academic leaders as thermostats. Tertiary Education and Management, 9(4), 281-298.

Kerr, K. A. (1996). Coordination and information: historical perspectives on the organization of enterprise. Business History Review, 70(1), 111-112.

Kidwell, R. E., \& Valentine, S. R. (2008). Positive group context, work attitudes and organizational misbehavior: the case of withholding job effort. Journal of Business Ethics, 86(1), 15-28.

Koen, M. P., \& Bitzer, E. M. (2010). Academic leadership in higher education: a 'participative' perspective from one institution. Academic Leadership: The Online Journal.

http://www.academicleadership.org/408/academic_leadership_in_higher_educatio n_a_participative_perspective_from_one_institution/

Kubicek, M. (2004). Mentoring makes its mark. Training Magazine. 5.

Loughlin, C., \& Barling, J. (2001). Young workers' work values, attitudes and behaviours. Journal of Occupational and Organizational Psychology, 74, 543-558.

Luthans, F. (1995). Organizational Behaviour. 7ed., New York: McGraw-Hill.

Manshor, A. T., Jusoh, M., \& Simun, M. (2002). Diversity factors and preferential treatments in selecting employees. Journal of Management Development, 22, 643-56.

Marshall, S. J., Adam, M. J., Cameron, A., \& Sullivan, G. (2000). Academics' perceptions of their professional development needs related to leadership and management: What can we learn? International Journal for Academic Development, 5(1), 42-53.

McNamara, M. S. (2009). Academic leadership in nursing: legitimating the discipline in contested spaces. Journal of Nursing Management, 17(4), 484-493.

Murphy, J. (2003). Reculturing Educational Leadership: The ISLLC Standards Ten Years Out, Paper prepared for the National Policy Board for Educational Administration, September.

Mowday, R. T., Steers, R. M., \& Porter, L. W. (1979). The measurement of organizational commitment. Journal of Vocational Behavior, 14, 244-247.

Noordin, F., \& Jusoff, K. (2010). Individualism-collectivism and job satisfaction between Malaysia and Australia. International Journal of Education Management, 24(2), 159174.

Oswald, S. L., Hossholder, K. W., \& Harris, S. G. (1994). Vision salience and strategic involvement: implications of psychological attachment to organization and job. Strategic Management Journal, 15, 477-489.

Piercy, N. F. (1999). A polemic in search of excellence among business school professors: cowboys, chameleons, question-marks and quislings. European Journal of Marketing, 33(7/8), 698-706.

Porter, L. W., Crampton, W. J., \& Smith, F. J. (1976). Organizational commitment and managerial turnover: A longitudinal study. Organizational Behavior and Human Performance, 15, 87-98.

Randall, L. M., \& Coakley, L. A. (2007). Applying adaptive leadership to successful change 
initiatives in academia. Leadership \& Organization Development Journal, 28(4), 328335.

Rekila, E., Larimo, M., \& Tauriainen, K. (1999). Do changing state steering mechanisms have an impact on academic leadership at universities. Tertiary Education and Management, 5(3), 261-277.

Roscoe, J. T. (1975). Fundamental Research Statistics for the Behavioral Sciences, 2ed., New York: Rinehart and Winston.

Rowley, D. J., \& Sherman, H. (2003). The special challenges of academic leadership. Management Decision, 41(10), 1058-1063.

Sagie, A., Zaidman, N., Amichai-Hamburger, Y., Te'eni, D., \& Schwartz, D. G. (2002). An empirical assessment of the loose-tight leadership model: Quantitative and qualitative analyses. Journal of Organizational Behavior, 23(3), 303-320.

Saktivel, P. B. (2007). Top management commitment and overall engineering education excellence. TQM Magazine, 19(3), 259-273.

Shirey, M. R. (2004). Social support in the workplace: nurse leader implications. Nursing Economics, 22(6), 313-319.

Spendlove, M. (2007). Competencies for effective leadership in higher education. International Journal of Educational Management, 21(5), 407-417.

Strathe, M. I., \& Wilson, V. W. (2006), Academic leadership: The pathway to and from. New Directions for Higher Education, 134, 5-13.

Tu, H. S., Forret, M. L., \& Sullivan, S. E. (2006). Careers in a non-western context: an exploratory empirical investigation of factors related to career success of Chinese managers. Career Development International, 11(7), 580-586.

Walumbwa, F. O., Lawler, J. J., Avolio, B. J., Wang, P., \& Shi, K. (2005a). Transformational leadership and work-related attitudes: the moderating effect of collective and selfefficacy across cultures. Organizational Studies, 11(1), 2-16.

Walumbwa, F. O., Orwa, B., Wang, P., \& Lawler, J. J. (2005b). Transformational leadership, organizational commitment and job satisfaction: a comparative study of Kenyan and US financial firms. Human Resource Management Development Quarterly, 16(2), 235256.

Weiss, D. J., Dawis, R. V., England, G. W., \& Lofquist, L. H. (1967). Manual for the Minnesota Satisfaction Questionnaire. Minnesota: University of Minnesota.

Yanez, M. L. H. (2004). An academic leadership-based group experience. Leadership \& Organization Development Journal, 25(3), 249-262.

Yiing, L. H., \& Ahmad, K. Z. (2009). The moderating effects of organizational culture on the relationships between leadership behaviour and organizational commitment and between organizational commitment and job satisfaction and performance. Leadership \& Organization Development Journal, 30(1), 53-86.

Zabid, A. R. M., \& Alsagoff, S. K. (1993). Perceived ethical values of Malaysian managers. Journal of Business Ethics, 12(4), 331-337.

Zhao, W., \& Ritchie, J. R. B. (2007). An investigation of academic leadership in tourism research: 1985-2004. Tourism Management, 28(2), 476-90. 